neofilolog

Czasopismo Polskiego Towarzystwa Neofilologicznego

ISSN 1429-2173, 2019, NR 53/1, 71-88

http://dx.doi.org/10.14746/n.2019.53.1.5

http://poltowneo.org/

Margorzata Banach

Uniwersytet Jagielloński w Krakowie https:// orcid.org/0000-0003-1207-7673

malgorzata.banach@uj.edu.pl

\title{
CERTYFIKATOWE TESTY Z JĘZYKA POLSKIEGO I ANGIELSKIEGO NA POZIOMIE C2 W UJĘCIU PORÓWNAWCZYM
}

\section{The certificate examination in English and Polish at C2 level: a comparative analysis}

The amendment to the Polish Language Act in 2015 has resulted in significant changes in the system of the state certificate examinations in Polish as a foreign language. One of the changes is a revised format of the certificate examination at C2 level. The author begins by briefly presenting the recent revisions to the test. The Polish examination is then compared with its English equivalent: C2 Proficiency, a renowned British test which has undergone numerous changes since its first administration in 1913. The comparative analysis is focused on the structure of both examinations and their parts, task types that are used and skills that are tested. Through showing similarities and differences between the analyzed language proficiency tests the author reflects on practical implications of various choices made by experts who are responsible for test design and development.

Keywords: language testing, Polish as a foreign language, comparative glottodidactics, state certificate examinations in Polish as a foreign language, Cambridge exams

Słowa kluczowe: testowanie znajomości języka, język polski jako obcy, glottodydaktyka porównawcza, państwowe egzaminy certyfikatowe z języka polskiego jako obcego, egzaminy Cambridge 


\section{Wprowadzenie}

Po ponad dziesięciu latach funkcjonowania certyfikacji znajomości języka polskiego jako obcego, powołanej do istnienia w 2003 roku$^{1}$, w roku 2015 w systemie państwowych egzaminów nastąpiły znaczne przeobrażenia związane z uchwaleniem przez Sejm RP kolejnej nowelizacji ustawy o języku polskim². Znowelizowane przepisy otwierają cudzoziemcom uczącym się polszczyzny między innymi możliwość uzyskania certyfikatu na poziomach od A1 do C2 Rady Europy (wcześniej było to możliwe jedynie na poziomach: B1, B2 i C2)3. Jedną z now ości wynikłych ze zmiany prawa jest również modyfikacja formatu egzaminu certyfikatowego na poziomie C2. W nowym kształcie przeprowadzono go jak dotąd dwukrotnie: podczas sesji egzaminacyjnych w listopadzie 2017 i 2018 roku4.

Pierwsza część niniejszego artykułu przynosi krótkie omówienie zmian, które po 2015 roku zaszły w polskim teście biegłości na poziomie C2. Egzamin z języka polskiego zostanie następnie zestawiony z analogicznym egzaminem z języka angielskiego - C2 Proficiency, przygotowywanym przez Uniwersytet w Cambridge i znanym do niedawna jako Certificate of Proficiency in English, w skrócie: CPE. Egzamin CPE po raz pierwszy zorganizowano w 1913 roku i w ciągu ponad stuletniej historii regularnie modyfikowano jego kształt. W obecnym formacie przeprowadzany jest on od 2013 roku. Pomimo że egzaminy mają odmienną tradycję oraz organizowane są na różną skalę, do analizy porównawczej skłania między innymi fakt, iż oba uznawane są przez ALTE (The Association of Language Testers in Europe).

Analiza deskryptorów zawartych w Europejskim systemie opisu kształcenia językowego (2003) (dalej: ESOKJ) oraz w uzupełniającej go publikacji Common European Framework of Reference for Languages: Learning, Teaching, Assessment. Companion Volume with New Descriptors (2018) (dalej: CEFR-CV) prowadzi do wniosku, iż test znajomości języka na poziomie C2 powinien umożliwić kandydatom wykazanie się wysoką kompetencją językową i - co się z tym wiąże - dużą sprawnością kognitywną. Te same nadrzędne cele

${ }^{1}$ System egzaminów certyfikatowych powstał na mocy Ustawy z dnia 11 kwietnia 2003 r. o zmianie ustawy o języku polskim (Dz. U. 2003 nr 73 poz. 661).

${ }^{2}$ Organizację egzaminów reguluje obecnie Ustawa z dnia 12 czerwca 2015 r. o zmianie ustawy o języku polskim oraz ustawy o organizacji i funkcjonowaniu funduszy emerytalnych (Dz. U. 2015 poz. 1132), a także dwa rozporządzenia ministerialne, w tym Rozporzq̨dzenie M inistra Nauki i Szkolnictwa Wyższego z dnia 26 lutego 2016 r. w sprawie egzaminów z języka polskiego jako obcego (Dz. U. 2016 poz. 405).

3 Jak dotąd nie przeprowadzono jednak jeszcze egzaminów na poziomie $A 1$.

${ }^{4}$ Kolejna sesja, podczas której będzie można zdawać egzamin na tym poziomie, odbędzie się 23-24 listopada 2019 roku. 
ogólne można jednak realizować za pomocą różnych rozwiązań szczegółowych. W artykule omówione zostaną więc: struktura obu testów biegłości, wykorzystywane typy zadań i sprawdzane umiejętności, jak również praktyczne implikacje określonych wyborów dokonanych przez twórców tych egzaminów. W analizie wykorzystano, między innymi, obowiązujące akty prawne, testy przykładowe oraz inne materiały publikowane przez instytucje odpowiedzialne za przygotowanie egzaminów, czyli Państwową Komisję ds. Poświadczania Znajomości Języka Polskiego jako Obcego oraz jednostkę Cambridge English Language Assessment działającą na Uniwersytecie w Cambridge; odwoływano się również do obserwacji własnych poczynionych podczas sesji egzaminów certyfikatowych z języka polskiego organizowanych przed nowelizacją ustawy i po niej.

\section{Zmiany w formacie egzaminu certyfikatowego zjęzyka polskiego na poziomie zaawansowanym po 2015 roku}

Różnice pomiędzy państwowym testem z języka polskiego na poziomie C2 przed nowelizacją ustawy w 2015 roku i po niej widoczne są już w strukturze samego

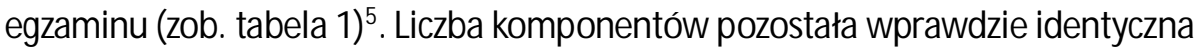
(są to kolejno: Rozumienie ze słuchu, Rozumienie tekstów pisanych, Poprawność gramatyczna, Pisanie oraz - zdawane w ten sam lub następny dzień - M ówienie), lecz nastąpiła zmiana w porządku ich przeprowadzania. Obie części testujące opanowanie sprawności receptywnych poprzedzają obecnie komponent gramatyczny (kolejność ta wydaje się bardziej naturalna, gdyż rozumienie poprzedza produkcję); wcześniej po części Rozumienie ze słuchu zdający rozwiązywali test poprawności gramatycznej, a dopiero po nim następowała kontrola sprawności czytania ze zrozumieniem. Wydłużono również czas przeznaczony na przeprowadzenie egzaminu z 4 godzin i 5 minut do maksymalnie 5 godzin ${ }^{6}$. Tym samym test na poziomie C2 jest najdłuższym egzaminem w nowym systemie. Wpływ na to miały modyfikacje w komponentach: Rozumienie tekstów pisanych oraz Mówienie. Liczba zadań w całym egzaminie pozostała przy tym podobna.

Kolejna zmiana strukturalna dotyczy punktacji. Zdający egzamin na poziomie C2 mogą obecnie zdobyć maksymalnie 210 pkt., podczas gdy dawniej

\footnotetext{
${ }^{5}$ Test przykładowy w formacie obowiązującym przed nowelizacją przepisów w 2015 roku zawiera publikacja Państwowe Egzaminy Certyfikatowe z Języka Polskiego jako Obcego. Przykładowy test dla poziomu zaawansowanego: PL-C2 (2008). Aktualny test przykładowy dla poziomu C2 można natomiast zobaczyć na stronie: http://certyfikatpolski.pl/dla-zdajacych/przykladowe-testy-zbiory-zadan/.

${ }^{6}$ Dopuszczalne są tu pewne wahania ze względu na to, że wypowiedzi ustne poszczególnych kandydatów mogą być zróżnicowane pod względem długości; czas odpowiedzi jednego zdającego nie powinien jednak przekraczać 30 minut.
} 
było to 200 pkt. (po 40 pkt. w każdej z 5 części). M a to związek ze zwiększeniem wagi komponentu Poprawność gramatyczna - można w nim teraz uzyskać 50 pkt., o 10 pkt. więcej niż poprzednio i o 10 pkt. więcej niż w każdej z pozostałych części.

\begin{tabular}{|l|c|c|l|c|c|}
\hline \multicolumn{3}{|c|}{ EGZAM IN NA POZOM IE C2 DO 2015 ROKU } & \multicolumn{3}{c|}{ EGZAM IN NA POZOM IE C2 PO 2015 ROKU } \\
\hline Komponent & Czas & Liczba zadań & Komponent & Czas & Liczba zadań \\
\hline Rozumienie ze słuchu & $30 \mathrm{~min}$. & 5 & Rozumienie ze słuchu & $30 \mathrm{~min}$. & 4 lub 5 \\
\hline Poprawność gramatyczna & $60 \mathrm{~min}$. & 8 & Rozumienie tekstów pisanych & $90 \mathrm{~min}$. & 5 \\
\hline Rozumienie tekstów pisanych & $45 \mathrm{~min}$. & 5 & Poprawność gramatyczna & $60 \mathrm{~min}$. & 8 \\
\hline Pisanie & $90 \mathrm{~min}$. & 2 lub 1 & Pisanie & $90 \mathrm{~min}$. & 1 \\
\hline Mówienie & $20 \mathrm{~min}$. & 2 & Mówienie & do $30 \mathrm{~min}$. & 2 \\
\hline Razem: & $\mathbf{4}$ godz. & $\mathbf{2 1}$ lub 22 & Razem: & do 5 godz. & $\mathbf{2 0}$ lub 21 \\
\hline
\end{tabular}

Tabela 1: Egzamin certyfikatowy z języka polskiego jako obcego na poziomie C2 do roku 2015 i po zmianach (opracowanie własne).

Przyjrzymy się teraz modyfikacjom wprowadzonym w poszczególnych komponentach egzaminu w nowym formacie ${ }^{7}$.

${ }^{7}$ Obowiązujące obecnie standardy wymagań zdefiniowane zostały w załączniku do Rozporzadzenia M inistra Nauki i Szkolnictwa Wyższego z dnia 26 lutego 2016 r. w sprawie egzaminów z języka polskiego jako obcego (Dz. U. 2016 poz. 405). W stosunku do Standardów wymagań egzamina cyjnych z roku 2003 w wymogach dla poziomu C2 po 2015 r. nastąpiły pewne zmiany. We fragmentach określających wymagania w zakresie sprawności receptywnych zrezygnowano np. ze sformułowania, że kandydaci powinni rozumieć teksty na tematy specjalistyczne, w zakresie których posiadają wiedzę (pojawiało się ono w Standardach wymagań egzaminacyjnych z 2003 roku). Obecnie w standardach podkreśla się, że zdający powinni rozumieć także teksty specjalistyczne, z wyłączeniem wysoko specjalistycznych. W opisie umiejętności oczekiwanych od zdających w części Poprawność gramatyczna w nowej wersji standardów bardziej szczegółowo wyliczono zagadnienia fleksyjne, składniowe i słowotwórcze, które należy opanować na poziomie zaawansowanym, dużo miejsca poświęcając ponadto kwestiom stylistycznym (jedynie sygnalizowanym w wersji z 2003 r.). Z wykazu gatunków tekstów, których redakcja może być sprawdzana w komponencie Pisanie, zniknęły formy krótkie typu: reklama, ogłoszenie, życzenia, zaproszenie itp. (umiejętność ich tworzenia podlega kontroli na niższych poziomach). Autorzy aktualnych standardów w części dotyczącej sprawności pisania podkreślają także rolę działań mediacyjnych i interakcyjnych w procesie kompozycji tekstów. W wykazie wypowiedzi ustnych w opisie wymagań w zakresie mówienia nie ma już rozmów telefonicznych, dialogów intencjonalnych i tematycznych (obecnych w Standardach wymagań egzaminacyjnych z 2003 roku), pojawiły się natomiast: debata i szczegółowy opis. Zob. Państwowe Egzaminy certyfikatowe z Języka Polskiego jako Obcego. Standardy wymagań egzaminacyjnych (2003: 46-56) oraz http://prawo.sejm.gov.pl/isap.nsf/download.xsp/WDU20160000405/O/D20160405.pdf. 
Certyfikatowe testy z języka polskiego i angielskiego na poziomie C2 w ujęciu...

Największą nowością w części Rozumienie ze słuchu jest kształt zadania pierwszego. Słuchając dziesięciu krótkich tekstów o charakterze informacyjnym, kandydaci mają uzupełnić brakujące informacje w podanych w arkuszu zdaniach niebędących transkrypcją nagrań. Jest to jedyne zadanie, w którym nagranie jest odtwarzane tylko jeden raz (w przeciwieństwie do starego testu, w którym wszystkie teksty odsłuchiwano dwukrotnie). Pojawienie się tego zadania oznacza zwiększenie liczby wypowiedzi, których rozumienie jest sprawdzane i jest utrudnieniem dla zdających. Zkomponentu zniknęły natomiast zadania wymagające wyboru zdań zgodnych ze słuchanym tekstem czy zadania z jednostkami na dobieranie ${ }^{8}$. W Rozumieniu ze słuchu wydają się dominować wypowiedzi monologowe - w tym z wplecionymi monologami (zob. Prizel-Kania, 2018: 88-89) - należące do masowego poziomu komunikowania: wiadomości i komentarze radiowe, felietony, co nie jest nową tendencją w testach certyfikatowych (zob. Prizel-Kania, 2018: 82). Próbę przełamania schematu można zauważyć w ostatnim zadaniu testu przykładowego - pytaniach wielokrotnego wyboru towarzyszących dialogom, z których część reprezentuje nieoficjalną odmianę języka. W zadaniu tym nacisk położony został na sprawdzanie rozumienia kontekstu, w jakim zachodzi interakcja, a także intencji, nastawienia i opinii rozmówców. Jednostki tego typu stanowiłyby nowość w omawianym komponencie, nie pojawiły się jednak we właściwych testach egzaminacyjnych.

Po roku 2015 znaczące zmiany zaszły też w komponencie Rozumienie tekstów pisanych na poziomie $\mathrm{C} 2^{9}$. Obecnie na rozwiązanie zadań wchodzących w skład tej części osoby ubiegające się o certyfikat na poziomie C2 mają 90 minut, podczas gdy przed nowelizacją przepisów było to jedynie 45 minut. Pozwala to na sprawdzanie rozumienia tekstów dłuższych niż w latach 20042015 - materiały zamieszczone w części Rozumienie tekstów pisanych w aktualnym teście przykładowym liczą łącznie około 2600 wyrazów, dla porównania: w teście przykładowym z 2008 roku miały one razem około 1800 wyrazów. Kandydaci - zamiast pięciu krótszych - czytają trzy długie teksty, ale nadal wykonują pięć zadań (dwóm z trzech tekstów towarzyszą po dwa zadania). W nowym teście nie pojawiły się (wykorzystywane w przeszłości) jednostki typu prawda/fałsz/brak informacji w klasycznej postaci, jeden raz kandydaci rozwiązywali jednak zadanie (niestosowane dawniej w tej części) wymagające wyboru stwierdzeń zgodnych z czytanym tekstem. W komponencie sprawdza

\footnotetext{
${ }^{8}$ Pozostałe informacje na temat technik stosowanych w tym komponencie zostaną podane w kolejnej części artykułu.

${ }^{9}$ Już w poprzednim systemie kształt tego komponentu ewoluował, po kilku pierwszych latach funkcjonowania certyfikacji zrezygnowano na przykład z testowania na poziomie C2 rozumienia pojedynczych napisów i akapitów.
} 
się obecnie szerszą gamę umiejętności, nowością są pytania dotyczące zasadniczej myśli tekstu, jego funkcji, intencji autora, w większym stopniu niż dawniej oczekuje się od kandydatów interpretacji, wnioskowania, odczytywania treści wyrażonych nie wprost (niektóre jednostki przypominają pytania maturalne z języka polskiego).

O dużych modyfikacjach można też mówić w przypadku komponentu Poprawność gramatyczna, mimo że zmianie nie uległy ani liczba zadań, ani czas przeznaczony na ich rozwiązanie. $Z$ testu zniknęły zadania w całości poświęcone sprawdzaniu kompetencji kandydatów w zakresie odmiany liczebników, tworzenia i użycia imiesłowów, użycia spójników czy czasowników prefiksalnych (spotykamy je natomiast w teście na poziomie $\mathrm{C1}$ ). Od zdających wymaga się obecnie wykonania bardziej złożonych operacji, a dominującym typem jednostek nie są już proste transformacje morfosyntaktyczne ${ }^{10}$. Zadania na transformacje składniowe opierają się na całych tekstach, a nie na pojedynczych zdaniach, przekształcenia słowotwórcze z kolei nie ograniczają się do tworzenia jednej części mowy czy zastosowania jednego mechanizmu słowotwórczego. Zupełną nowość stanowią: zadanie z lukami otwartymi (tzw. cloze lub "dziurawiec"), jednostki typu „poprawa błędów” (mogą one być zarówno gramatyczne, jak i leksykalne), zadanie typu „krótka odpowiedź” wymagające wpisania wyrażenia (często idiomatycznego) o przeciwnym znaczeniu do podanego. W trakcie analizy testu nasuwa się wniosek, iż nazwa komponentu nie do końca odpowiada jego zawartości. W zintegrowany sposób testowana jest w nim bowiem poprawność językowa; akcent położono nie tylko na znajomość systemu gramatycznego, ale także leksykalnego. Ponieważ oba podsystemy są ze sobą powiązane, samą modyfikację kształtu tej części należy ocenić pozytywnie.

W części Pisanie pojawiają się teraz tylko dwa tematy wypowiedzi, z których zdający wybierają jeden. Jest to znacząca zmiana, gdyż poprzednio mieli do wyboru 4 zestawy składające się najczęściej z dwóch zadań (jeden z zestawów mógł jednak wymagać realizacji jednej długiej formy). Preferowanymi przez autorów komponentu gatunkami wydają się esej i tekst argumentacyjny (rozprawka). Oznacza to, że zmniejszono liczbę sprawdzanych form pisemnych (zrezygnowano z tematów wymagających redakcji np. opowiadania, artykułu, listu formalnego, przemówienia, sprawozdania). W nowym systemie kandydaci tworzą teksty liczące 500 słów (dawniej limit ten wynosił 400 wyrazów).

Część ustną wydłużono z 20 do 30 minut. Inaczej wyglądają również zestawy zadań i struktura komponentu Mówienie. Poprzednio zdający prezentowali

${ }^{10}$ Przykładowo, w jednym z zadań testowana jest nie tylko umiejętność odmiany trudniejszych czasowników, lecz sprawdza się również rozumienie tekstu i znajomość kolokacji (potrzebne czasowniki zostały podane nie w nawiasach obok luk, lecz w banku możliwości). 
Certyfikatowe testy z języka polskiego i angielskiego na poziomie C2 w ujęciu...

dwa monologi. Pierwsza wypowiedź wymagała syntezy informacji zebranych w formie kolażu elementów graficznych i krótkich fragmentów tekstów (całość mieściła się na stronie formatu A4), druga - ustnego streszczenia tekstu długości strony A4 oraz wyrażenia opinii na jego temat. Pierwsze zadanie części ustnej w obecnym formacie łączy w sobie elementy obu zadań typowych dla egzaminu w starym kształcie - kandydat ma dokonać syntezy 3 różnych powiązanych tematycznie dokumentów, wśród których są dłuższe teksty, cytaty, ilustracje, wykresy i diagramy. Zadanie drugie to wypowiedź argumentacyjna na zadany temat oraz dyskusja z komisją.

Analiza zmian, jakim uległ egzamin na poziomie C2, prowadzi do wniosku, że test certyfikatowy w nowym formacie jest bardziej wymagający pod względem językowym i kognitywnym od egzaminu w dawnej postaci, nastawiony w większym stopniu niż poprzednio na sprawdzanie umiejętności przydatnych w sferze akademickiej: pracy z dłuższymi tekstami i ich interpretacji, krytycznej analizy i syntezy informacji zawartych w różnych źródłach, tworzenia rozbudowanej wypowiedzi ustnej oraz argumentowania.

\section{Nowy egzamin certyfikatowy z języka polskiego na poziomie zaawansowanym a egzamin Cambridge $\boldsymbol{C}$ Proficiency ${ }^{11}$}

Porównanie państwowego egzaminu certyfikatowego z języka polskiego jako obcego na poziomie C2 oraz egzaminu C2 Proficiency ${ }^{12}$ pozwala dostrzec występujące między nimi różnice strukturalne dotyczące: liczby i układu komponentów, liczby zadań oraz czasu przeznaczonego na rozwiązanie obu testów biegłości (zob. tabela 2). Analizowany egzamin Cambridge składa się z mniejszej liczby komponentów niż egzamin z języka polskiego na poziomie zaawansowanym i trwa od niego krócej - 3 godz. 46 minut. W tym czasie kandydaci stykają się z 17 zadaniami - zdający egzamin z języka polskiego rozwiązują ich natomiast więcej - 20 lub 21 (w zależności od sesji). W części pisemnej egzaminu C2 Proficiency sprawdzane są kolejno: sprawność czytania razem z poprawnym użyciem języka (Reading and Use of English), pisanie (Writing) oraz rozumienie ze słuchu (Listening). Część ustna (Speaking) zdawana jest w inny dzień niż pisemna. Zaskakujące wydaje się umiejscowienie komponentu Listening

\footnotetext{
${ }^{11} \mathrm{~W}$ dalszej części niniejszego tekstu egzamin certyfikatowy z języka polskiego na poziomie C2 będzie także określany jako: egzamin polski lub test polski, natomiast wymiennie z nazwą egzamin C2 Proficiency używane będą nazwy: egzamin angielski, test angielski, egzamin brytyjski oraz test brytyjski.

${ }^{12}$ Przykładowy test C2 Proficiency odnaleźć można pod adresem: https:// www.cambri dgeenglish.org/exams-and-tests/proficiency/preparation/.
} 
na samym końcu egzaminu pisemnego, kiedy kandydaci są najbardziej zmęczeni (zob. Seretny, Lipińska, 2005: 160). Rozwiązanie przyjęte z kolei w systemie polskim, czyli rozpoczęcie egzaminu od tego właśnie testu, który dla wielu kandydatów jest najbardziej stresujący, również może mieć negatywny wpływ na uzyskiwane przez nich wyniki (por. Bachman, 1990: 120-121).

\begin{tabular}{|c|c|c|c|c|c|}
\hline \multicolumn{3}{|c|}{ EGZAMIN ZJEZZYKA POLSKIEGO NA POZOMIEC2 } & \multicolumn{3}{|c|}{ EgZamin CPRofaency } \\
\hline Komponent & Czas & Liczba zadań & Komponent & Czas & Liczba zadań \\
\hline Rozumienie ze słuchu & $30 \mathrm{~min}$. & 4 lub 5 & Reading and Use of English & $90 \mathrm{~min}$. & 7 \\
\hline Rozumienie tekstów pisanych & $90 \mathrm{~min}$. & 5 & Writing & $90 \mathrm{~min}$. & 2 \\
\hline Poprawność gramatyczna & $60 \mathrm{~min}$. & 8 & Listening & $30 \mathrm{~min}$. & 5 \\
\hline Pisanie & 90 min. & 1 & \multirow{2}{*}{ Speaking } & \multirow{2}{*}{$16 \mathrm{~min}}$. & \multirow{2}{*}{3} \\
\hline Mówienie & do $30 \mathrm{~min}$. & 2 & & & \\
\hline Razem: & do 5 godz. & 21 lub 22 & Razem: & $\begin{array}{l}3 \text { godz. } \\
46 \mathrm{~min}\end{array}$ & 17 \\
\hline
\end{tabular}

Tabela 2: Egzamin certyfikatowy z języka polskiego jako obcego na poziomie C2 a egzamin C2 Proficiency (opracowanie własne).

Do istotnych różnic w zakresie struktury analizowanych testów należą także przyjęte w nich sposoby przeliczania punktów oraz progi zdawalności. Każdy punkt zdobyty na egzaminie polskim odpowiada jednemu punktowi w wyniku końcowym, a liczba punktów możliwych do zdobycia jest we wszystkich komponentach, z wyjątkiem Poprawności gramatycznej, identyczna. Narzuca to pewne ograniczenia zespołom odpowiedzial nym za przygotowanie poszczególnych części egzaminu ze względu na konieczność uwzględnienia tego samego limitu punktów w komponentach o różnej specyfice. W Cambridge przyjęto bardziej elastyczne rozwiązanie: każdy komponent ma swoją własną, odmienną od innych, punktację wynikającą z jego wewnętrznej struktury, lecz poszczególnym sprawnościom oraz poprawności językowej przyznano identyczną wagę w całości egzaminu. Surowe rezultaty punktowe uzyskane przez kandydatów w kolejnych częściach egzaminu są następnie ważone według ściśle określonych zasad ${ }^{13}$, natomiast o ocenie końcowej decyduje ich średnia.

Osoba przystępująca do egzaminu z języka polskiego otrzyma certyfikat, jeśli w każdej z pięciu części uzyska przynajmniej 60\% możliwych do zdobycia punktów. System Cambridge jest dla zdających bardziej przyjazny - aby zdać egzamin C2 Proficiency, należy uzyskać określony wynik z testu jako całości ${ }^{14}$, kandydat, który osiągnie rezultat tuż poniżej tego progu, może natomiast dostać

${ }^{13}$ Przybliżone one zostały na stronie: https://www.cambridgeenglish.org/exams-and-te sts/cambridge-english-scale/

${ }^{14}$ Średnia z wszystkich części po zważeniu musi wynieść przynajmniej 200. 
poświadczenie o znajomości języka na poziomie C1. Rozwiązania takiego nie przewidują przepisy regulujące funkcjonowanie systemu polskiej certyfikacji.

Poniżej przedstawione zostanie porównanie poszczególnych komponentów obu testów biegłości, a wyniki analizy będą prezentowane w porządku wyznaczanym przez kształt egzaminu z języka polskiego.

Część Rozumienie ze słuchu trwa około 10 minut krócej od komponentu Listening (jednak na tym ostatnim 5 z 40 minut to czas przeznaczony na zaznaczenie odpowiedzi na osobnym, specjalnie do tego przeznaczonym arkuszu). W obu komponentach podobna jest liczba zadań - w polskim jest ich 4 lub 5 zależnie od sesji, a w brytyjskim zawsze 5, jednak dwa zadania w części Listening odnoszą się do tej samej serii monologów (w sekcji 4. tego komponentu). Pomimo podobnej liczby zadań duża dysproporcja występuje między liczbą pytań w obu porównywanych komponentach, gdyż Rozumienie ze słuchu składa się z 50 jednostek testu ${ }^{15}$, natomiast część Listening ma ich tylko 30. Rozwiązanie brytyjskie wydaje się bardziej przemyślane, istnieje bowiem większe prawdopodobieństwo, że ze względu na mniejszą liczbę pytań do nagrań o łącznym dłuższym czasie trwania fragmenty kluczowe dla udzielenia odpowiedzi nie wystąpią w tekście zbyt blisko siebie, a kandydaci będą mogli lepiej skupić się na słuchanym materiale. Kształt testu polskiego natomiast niesie ze sobą ryzyko, że w momencie, gdy zdający będą koncentrować się na wyborze lub sformułowaniu danej odpowiedzi, w nagraniu mogą pojawić się informacje potrzebne dla rozwiązania kolejnej jednostki. Ułatwienie dla starających się o certyfikat Cambridge stanowi również fakt, że w odróżnieniu od egzaminu polskiego wszystkie nagrania w części Listening odtwarzane są dwukrotnie.

Podczas egzaminu zjęzyka polskiego na poziomie C2 sprawdza się rozumienie większej liczby tekstów mówionych (od 13 do 16) niż na egzaminie C2 Proficiency (tam jest ich w sumie 10). Inaczej niż w systemie polskim, autorzy egzaminu z angielskiego dość precyzyjnie określają rodzaje tekstów, jakie pojawią się w kolejnych zadaniach na rozumienie ze słuchu. Nie przewiduje się w nim obecności wypowiedzi z wplecionymi monologami (wykorzystywanych z kolei na egzaminie polskim) - kandydaci stykają się zatem albo z klasycznymi komunikatami monologowymi, albo - rzadziej - z rozmowami ${ }^{16}$. W obu porównywanych komponentach dominują wypowiedzi należące do masowego poziomu komunikowania.

\footnotetext{
${ }^{15}$ Przez jednostkę testu rozumiemy „najmniejszy element testu, za który przyznawany jest oddzielny punkt albo punkty" (Angielsko-polsko-słoweński glosariusz terminów z zakresu testowania biegłości językowej, 2004: 77).

${ }^{16}$ Co ciekawe, proporcje pomiędzy wypowiedziami interakcyjnymi a monologami w obu testach przykładowych są podobne (interakcje stanowią od 20 do 25\% wszystkich słuchanych komunikatów).
} 
Przygotowując zadania sprawdzające rozumienie ze słuchu, autorzy polscy sięgają po większą liczbę technik niż twórcy części Listening. Zdający egzamin polski mogą spotkać się w jego pierwszej części z jednostkami typu: uzupełnianie brakujących informacji (zadanie z lukami), dobieranie wielokrotne, wielokrotny wybór, krótka odpowiedź otwarta, prawda/fałsz, porządkowanie podtytułów w kolejności pojawiania się informacji w tekście. W komponencie polskim - inaczej niż w angielskim - nie wypracowano jak dotąd stałego schematu (oba testy użyte na egzaminie różniły się nieco od testu przykładowego, a także od siebie), co stwarza pewne zagrożenie dla jakości testu, jak również może negatywnie wpływać na jego odbiór przez zdających.

W komponencie Listening odnajdziemy tylko trzy techniki (dwie znich stosują także autorzy zadań w części Rozumienie ze słuchu): wielokrotny wybór, uzupełnianie brakujących informacji w tekście oraz dobieranie. Ponieważ, jak już powiedzieliśmy, komponent Listening składa się z pięciu zadań, oznacza to, że dwie techniki (a konkretnie: dobieranie i wielokrotny wybór) wykorzystywane są w nim po dwa razy, czego unikają na ogół autorzy testu polskiego. W porównywanych testach odmienne też bywa zastosowanie tych samych technik w konkretnych zadaniach. Przykładowo, zdający egzamin z języka polskiego uzupełniają 20 luk w tekście brakującymi informacjami, słuchając tylko jeden raz 10 różnych wiadomości, a zdający egzamin angielski wpisują 9 brakujących informacji w jednym dłuższym tekście, który prezentuje wybrane zagadnienie ${ }^{17}$. Ze względu na jednorodność tematyki i możliwość dwukrotnego odsłuchania tekstu zadanie z lukami w wersji brytyjskiej ma kształt bardziej przyjazny dla zdających.

Analizując oba komponenty, można zauważyć, że w zadaniach sprawdzających rozumienie ze słuchu na egzaminie polskim testuje się nieco węższy zakres umiejętności. Dominują tu jednostki testu spraw dzające przede wszystkim rozumienie selektywne i szczegółowe, natomiast w teście z języka angielskiego duże znaczenie przykłada się także do umiejętności określenia kontekstu i nastawienia wypowiadających się osób.

Odmienne rozwiązanie strukturalne twórcy obu egzaminów przyjęli również w częściach sprawdzających kompetencję kandydatów w zakresie recepcji pisemnej i poprawnego użycia języka. Rozumienie tekstów pisanych i Poprawność gramatyczna to na egzaminie certyfikatowym z języka polskiego dwa oddzielne komponenty, z którymi na poziomie C2 zdający pracują przez odpowiednio: 90 i 60 minut. Od roku 2013 natomiast egzamin brytyjski na tym poziomie łączy kontrolę obu aspektów znajomości języka w jednym komponencie o nazwie Reading and Use of English, na którego rozwiązanie kandydaci

${ }^{17}$ Tematy poruszane w nagraniach to przykładowo: wpływ określonej barwy na ludzi i zwierzęta, właściwości żywicy śródziemnomorskiej, realia życia zawodowego pilotów. 
mają w sumie 90 minut $^{18}$. Co ciekawe, pomimo tej integracji strukturalnej test przygotowany został w taki sposób, by na wydawanym certyfikacie można było zamieścić osobno informację o wyniku z części Use of English i z części Reading.

Zestawiając ze sobą analogiczne komponenty, widzimy, iż zdający egzamin z języka polskiego w ciągu dwóch i pół godziny rozwiązują ponad 110 jednostek testu w 13 zadaniach: pięciu (liczących łącznie ponad 40 jednostek testu) w komponencie Rozumienie tekstów pisanych i w ośmiu zadaniach (liczących 70 jednostek) w komponencie Poprawność gramatyczna. Na egzaminie C2 Proficiency w ciągu półtorej godziny należy udzielić odpowiedzi na 53 pytania w 7 zadaniach, z których cztery pierwsze sprawdzają poprawne użycie języka, a kolejne trzy - czytanie ze zrozumieniem (30 jednostek w komponencie dotyczy znajomości systemu, a pozostałe 23 to pytania na rozumienie tekstów).

Ze względu na dużą liczbę zadań i jednostek w przypadku egzaminu polskiego istnieje ryzyko, że na wynik kandydatów mogą wpłynąć czynniki pozajęzykowe, np. zmęczenie. Bardzo rozbudowane, szczegółowe narzędzia testowe są również mniej praktyczne, ponieważ przygotowanie, czynności administracyjne oraz poprawa dłuższego egzaminu wiążą się z większym nakładem czasu, a także kosztów. Ograniczenie liczby zadań i jednostek w teście grozi z kolei tym, iż niektóre ważne umiejętności zostaną w kontroli pominięte. Z tego powodu, autorzy zmian w formacie egzaminu Cambridge na poziomie C2 z roku 2013 rozważali między innymi kwestię, w jaki sposób dokonać integracji komponentów i zrezygnować z niektórych zadań bez zmniejszenia trafności konstrukcyjnej i rzetelności testu (Lim, 2013: 13; Zeronis, Elliott, 2013: 24).

W podejściu do ewaluacji sprawności czytania ze zrozumieniem w porównywanych testach biegłości zaobserwować można zarówno podobieństwa, jak i różnice. W obu przypadkach kandydaci pracują z trzema tekstami, których łączna długość jest zbliżona. Oznacza to, że zdający egzamin Cambride - rozwiązujący w ciągu półtorej godziny nie tylko zadania na rozumienie tekstów, ale także te dotyczące poprawności językowej - muszą zadany materiał czytać w szybszym tempie niż kandydaci na egzaminie polskim. Koniecznością staje się w takiej sytuacji wypracowanie przez nich odpowiednich strategii (Banach, 2018: 71).

Konstruując zadania, Polacy i Brytyjczycy sięgają m.in. po niespecjalistyczne artykuły prasowe czy fragmenty książek ( $w$ teście angielskim jest to współczesna proza, w polskim - pozycje nieliterackie, np. biografie). Na egzaminie z języka polskiego pojawiają się także niekiedy formy felietonistyczne czy eseistyczne, teksty o tematyce filozoficznej, bliższe odbiorcom o wykształceniu humanistycznym, mniej uniwersalne, jeśli chodzi o profil potencjalnego

${ }^{18}$ Przed rokiem 2013 części Reading i Use of English stanowiły odrębne komponenty egzaminu CPE. 
czytelnika niż te wykorzystywane na egzaminie Cambridge. Pozwala to sprawdzić wiele umiejętności niezbędnych w pracy z tekstem na tym poziomie, może jednak w gorszej sytuacji stawiać kandydatów o innych zainteresowaniach (zob. Bachman, 1990: 137-138).

Podczas gdy w części Rozumienie tekstów pisanych trzem tekstom towarzyszy pięć zadań, na egzaminie angielskim każdy z trzech tekstów stanowi podstawę tylko jednego zadania i - jak w pozostałych komponentach egzaminu C2 Proficiency - obowiązuje tu stały schemat. Techniki wspólne dla obu testów sprawności czytania to: pytania typu wielokrotny wybór oraz uzupełnianie luk w tekście wyjętymi z niego fragmentami. Inaczej niż w komponencie polskim, w teście brytyjskim z tekstu wyjmowane są jednak całe akapity, a nie pojedyncze zdania, co czyni jego rekonstrukcję trudniejszą ze względu na mniej wyraźne sygnały spójności. Na egzaminie polskim funkcjonuje również wariant alternatywny do zadania z lukami, w którym do fragmentów tekstu należy dobrać odpowiednie śródtytuły. Podczas jednego z dwóch egzaminów na poziomie C2 przeprowadzonych dotychczas po 2015 roku w części sprawdzającej rozumienie tekstów wykorzystano także zadanie z jednostkami wymagającymi wyboru zdań zgodnych z czytanym tekstem.

W komponencie Rozumienie tekstów pisanych nie znajdziemy zadania zjednostkami na dobieranie wielokrotne (obecnego w teście angielskim), pojawiają się w nim natomiast jednostki typu wielokrotny wybór leksykalny (wymagające wskazania słowa, które najlepiej pasuje w danej luce w tekście). Co ciekawe, ta ostatnia technika na egzaminie C2 Proficiency wliczana jest obecnie do wyniku z części Use of English, w poprzednim formacie egzaminu stosowano ją natomiast w komponencie sprawdzającym kompetencję kandydatów w zakresie sprawności czytania.

Porównanie omawianych komponentów pod kątem sprawdzanych przez nie umiejętności pokazuje, że w obu systemach przewiduje się kontrolę rozumienia globalnego, selektywnego i szczegółowego oraz umiejętności wnioskowania (zob. Komorowska, 2002: 144). Charakterystyczną cechą komponentu Rozumienie tekstów pisanych jest obecność zadania sprawdzającego w całości wyłącznie rozumienie szczegółów (w postaci wybranych fraz i zdań z tekstu). Także na egzaminie polskim pojawia się obecnie więcej pytań dotyczących funkcji tekstu, jego głównej myśli i intencji autora. Podczas egzaminu C2 Proficiency zawsze sprawdza się rozumienie struktury tekstu, natomiast w teście polskim zadanie tego typu może zostać zastąpione jednostkami testującymi globalne rozumienie kolejnych fragmentów tekstu. Na egzaminie brytyjskim premiuje się również umiejętność szybkiego wyszukiwania konkretnych informacji (m.in. dzięki ograniczeniu czasu i obecności jednostek na dobieranie wielokrotne).

Sprawdzając poprawne użycie języka, autorzy egzaminu C2 Proficiency wykorzystują mniej technik niż autorzy testu z języka polskiego. W części Use 
Certyfikatowe testy z języka polskiego i angielskiego na poziomie C2 w ujęciu...

of English są to: wielokrotny wybór leksykalny, jednostki z lukami otwartymi (tzw. „dziurawiec"), transformacje słowotwórcze oraz transformacje składniowe z użyciem wskazanego słowa (te ostatnie, inaczej niż w teście polskim, oparte na izolowanych zdaniach). Zadania tego typu - z wyjątkiem wielokrotnego wyboru leksykalnego - znajdziemy także w części Poprawność gramatyczna egzaminu na poziomie zaawansowanym. Techniki stosowane tylko w komponencie Poprawność gramatyczna to: odpowiedź otwarta, poprawa błędów, przekształcenia morfosyntaktyczne.

Autorzy obu egzaminów testują opanowanie gramatyki i słownictwa, lecz wydaje się, że w zadaniach testu angielskiego na poziomie C2 nieco większy nacisk kładzie się na leksykę niż system gramatyczny (istotna okazuje się znajomość odcieni znaczeniowych słów, wyrażeń idiomatycznych, kolokacji). Polska Poprawność gramatyczna w obecnym kształcie w znacznie większym stopniu niż w latach 2004-2015 przypomina komponent Use of English i sprawdza kompetencję leksykalną kandydatów, ale także znajomość gramatyki - zgodnie z nazwą - ma dla jej rozwiązania bardzo duże znaczenie. Ze względu na większą liczbę zadań i jednostek testu opanowanie systemu języka testuje się podczas egzaminu z języka polskiego na poziomie zaawansowanym bardziej szczegółowo niż na egzaminie C2 Proficiency. Na egzaminie polskim wymaga się też od zdających przepisywania w całości przekształcanych składniowo fragmentów, co jest stosunkowo czasochłonne i sprawia, że mniej czasu pozostaje na rozwiązanie innych zadań.

Części poświęcone sprawdzaniu umiejętności kandydatów w zakresie produkcji pisemnej (Pisanie i Writing) trwają na obu egzaminach po 90 minut. Przystępujący do egzaminu z języka polskiego na poziomie $C 2$ mają mniejszy wybór w zakresie tematów i gatunków niż zdający test biegłości Cambridge. Ubiegający się o certyfikat brytyjski tworzą bowiem nie jedną dłuższą wypowiedź z dwóch podanych do wyboru (jak ma to miejsce na egzaminie polskim), lecz dwa wypracowania. Zadanie pierwsze - wspólne dla wszystkich - wymaga napisania eseju w akademickim stylu, zawierającego syntezę i ocenę treści prezentowanych w dwóch krótkich fragmentach o tej samej tematyce. W drugim zadaniu zdający wybierają jeden spośród pięciu tematów, pojawiające się formy to: artykuł, recenzja, raport, list, esej. Dwa tematy w tej części nawiązują do lektur, z którymi zainteresowani mogą zapoznać się w ramach przygotowania do egzaminu. Jak zaznaczają organizatorzy, nie wymaga się od piszących stworzenia analizy krytycznoliterackiej, lecz dobrej znajomości wybranego dzieła oraz umiejętności przywołania jego wątków i tematów w komponowanym tekście o wskazanej w poleceniu formie ${ }^{19}$ (Cambridge English Proficiency. Handbook for teachers for exams from 2016, 2016: 24).

${ }^{19}$ M oże to być artykuł, recenzja, raport, list lub esej. 
Na egzaminie polskim wymaganą liczbę słów w wypracowaniu (500 wyrazów) wskazano na arkuszu, podczas oceniania pracy nie odejmuje się jednak punktów za odstępstwa od tej długości o 10\%. Na egzaminie angielskim zdający informowani są, w jakich granicach powinni się zmieścić, napisanie krótszego bądź dłuższego tekstu nie skutkuje jednak automatycznie utratą punktów. W części Writing należy w sumie napisać więcej niż w części Pisanie (sugerowana łączna długość prac redagowanych na egzaminie C2 Proficiency to 520-600 wyrazów), lecz każdy z redagowanych tekstów ma być stosunkowo krótki (długość pierwszego to 240-280 słów, a drugiego - 280-320 słów).

Zaletą rozwiązań przyjętych przez Brytyjczyków jest większy wybór tematów dany kandydatom, natomiast nie do końca przemyślane wydają się na poziomie C2 niskie limity słów dla poszczególnych tekstów ${ }^{20}$. Na egzaminie polskim zdający mogą się skoncentrować na redakcji jednego, dłuższego tekstu. Rozwiązanie to należy ocenić pozytywnie, aczkolwiek wątpliwości budzi duże ograniczenie, jeśli chodzi o liczbę tematów i form, spośród których kandydaci mogą dokonać wyboru.

W ostatnim komponencie obu testów biegłości (w częściach Mówienie i Speaking) oceniana jest wypowiedź ustna kandydata. W przeciwieństwie do egzaminu polskiego na egzaminie C2 Proficiency nie przewidziano czasu na przygotowanie się do wypowiedzi, a zdający odpowiadają nie pojedynczo, lecz w parach. Część Speaking ma strukturę trójdzielną i obejmuje: krótką rozmowę egzaminatora z kandydatami na ich temat, zadanie wykonywane w parach wymagające przedyskutowania określonego problemu i wspólnego podjęcia decyzji przez zdających (bodziec stanowią zestaw ilustracji i pytania osoby egzaminującej), jak również dwuminutowe monologi na zadany temat, następujące po nich pytania egzaminatora i dyskusję koncentrującą się wokół problematyki obu wypowiedzi monologowych. W porównaniu z egzaminem polskim marginalną rolę odgrywa tu słowo pisane (tylko niektóre polecenia kandydaci otrzymują w formie pisemnej, nie wymaga się od nich lektury tekstów). W części Speaking sprawdza się: umiejętność wyrażania i uzasadniania własnych o pinii, budowania krótkiej wypowiedzi, sprawność interakcyjną i mediacyjną (zwłaszcza mediowanie pojęć; zob. CEFR-CV, 2018: 117-121). Kształt egzaminu ustnego zjęzyka angielskiego sprawia też, że niezwykle ważną rolę odgrywają podczas niego: kreatywność, umiejętność improwizacji, odporność na stres. Format egzaminu właściwie uniemożliwia zbudowanie przemyślanej wypowiedzi. Duży wpływ na wynik zdającego może mieć także zachowanie jego partnera w dyskusji. Zdrugiej strony, funkcjonowanie w języku obcym wymaga wchodzenia w różnorakie interakcje w sposób elastyczny i płynny, i tę umiejętność sprawdza się w komponencie Speaking egzaminu C2 Proficiency.

${ }^{20}$ Już w fazie pilotażu najlepsi uczestnicy regularnie je przekraczali (Zeronis, Elliott, 2013: 25). 
Certyfikatowe testy z języka polskiego i angielskiego na poziomie C2 w ujęciu...

Część ustna egzaminu z języka polskiego, podczas której kandydat wygłasza dwa przygotowane wcześniej monologi i wchodzi w dyskusję z komisją, jest o wiele mniej dynamiczna i bardziej przewidywalna od egzaminu ustnego z języka angielskiego, mimo iż może od niego trwać prawie dwa razy dłużej (do 30 minut w porównaniu z 16 minutami części Speaking). Większy nacisk położony został tu na zdolności akademickie: umiejętność syntezy informacji zawartych w różnych źródłach (w tym mediacji tekstów), argumentowania, komponowania ustrukturyzowanej, długiej wypowiedzi ustnej. Egzamin ustny w takiej formie jest jednak czasochłonny i przy dużej liczbie kandydatów jego przeprowadzenie stanowiłoby wyzwanie organizacyjne ${ }^{21}$.

\section{Podsumowanie}

Z przeprowadzonych analiz obok wielu szczegółowych obserwacji płynie kilka ogólnych wniosków.

M odyfikacje wprowadzone po 2015 roku do certyfikatowego testu z języka polskiego na poziomie C2 doprowadziły do jego rozbudowania oraz wydłużenia. Pod pewnymi względami test ten stanowi obecnie większe wyzwanie dla kandydatów niż egzamin w dawnym kształcie. Ewolucję kilka lat temu przeszedł także analogiczny egzamin Cambridge, w tym przypadku odmienny był jednak kierunek zmian22: test skrócono i uproszczono jego format.

W częściach testowych egzaminu polskiego dostrzec można większe bogactwo stosowanych technik, ale także bardziej drobiazgowe podejście do testowania niż w odpowiadających im komponentach egzaminu C2 Proficiency. Biorąc pod uwagę progi zdawalności przyjęte w obu systemach, polski egzamin należy uznać też za bardziej restrykcyjny.

Sprawdzając umiejętności kandydatów w zakresie tych samych działań językowych i obszarów kompetencji, twórcy obu testów często inaczej rozkładają akcenty w analogicznych komponentach. Sprawia to, że w każdym z egzaminów można odnaleźć przykłady zadań bardziej złożonych i zadań łatwiejszych od tych użytych w drugim. Trzeba również pamiętać, że na poziom trudności

\footnotetext{
${ }^{21} \mathrm{Ma}$ to m.in. związek z faktem, że egzamin ustny dla zdających na wszystkich poziomach przeprowadzany jest tego samego dnia. Egzamin na poziomie C2 po 2015 roku wybrała jednak niewielka liczba zdających: we wszystkich ośrodkach egzaminacyjnych było ich łącznie czterdzieścioro sześcioro. M ożna przypuszczać, że tendencja ta będzie się utrzymywać, tym bardziej, że w systemie polskiej certyfikacji pojawił się egzamin na poziomie $\mathrm{C1}$, którego przed rokiem 2015 nie było.

${ }^{22}$ Ich dokładny opis wykracza poza problematykę tego artykułu (zob. Zeronis, Elliot, 2013; Docherty, Howden, 2013).
} 
jednostek w pływ ma bardzo wiele czynników (zob. Bachman, 1990); zdarza się zatem, że to samo zadanie będzie pod pewnymi względami prostsze, a pod innymi - bardziej wymagające niż podobne zadanie w innym teście ${ }^{23}$.

Inna ważna obserwacja dotyczy profilu modelowego kandydata. Wydaje się, iż egzamin z języka polskiego na poziomie zaawansowanym w nieco większym stopniu niż test C2 Proficiency sprawdza umiejętności przydatne na studiach humanistycznych (ma to związek przede wszystkim z kształtem części: Rozumienie tekstów pisanych, Pisanie i M ówienie). Egzamin brytyjski, choć również odwołuje się do kompetencji akademickich zdających (zob. Docherty, Howden, 2013: 20), jest pod tym względem bardziej uniwersalny.

Na koniec warto podkreślić jeszcze jedną różnicę. Brytyjczycy szczegółowo określają obowiązujący schemat egzaminu, którego muszą przestrzegać autorzy zadań i osoby odpowiedzialne za ostateczny kształt komponentów, i informują o nim na swoich stronach oraz w publikowanych materiałach. W polskim systemie certyfikacji rolę informacyjną pełni głównie test przykładowy, lecz na samym egzaminie na poziomie C2 w komponentach sprawdzających umiejętności kandydatów w zakresie sprawności receptywnych pojawiają się od niego pewne odstępstwa. Organizatorzy egzaminów Cambridge niewątpliwie stanowią wzór do naśladowania, jeśli chodzi o sposób zarządzania systemem i wprowadzania zmian, które są długo i starannie przygotowywane oraz odpowiednio wcześnie ogłaszane. M odyfikację kształtu testów certyfikatowych poprzedza m.in. szczegółowa analiza istniejących oraz proponowanych rozwiązań, podejmowana z dbałości o jakość egzaminów. Ogłaszanie planowanych zmian z wyprzedzeniem zmniejsza natomiast ryzyko, iż na wynik kandydatów wpłyną czynniki pozajęzykowe, jak np. nieznajomość formatu zadań (zob. ESOKJ, 2003: 139). W certyfikacji języka polskiego jako obcego, systemie stosunkowo młodym, lecz otwartym na naukę płynącą z cudzych doświadczeń i na korekty, warto do takiego standardu dążyć.

\section{BIBLIOGRAFIA}

Angielsko-polsko-słoweński glosariusz terminów z zakresu testowania biegłości językowej (2004), Kraków: Universitas.

Bachman L.F. (1990), Fundamental considerations in language testing. Oxford: Oxford University Press.

Banach M. (2018), Rozumienie tekstu pisanego przez zdajqacych egzamin certyfikatowyz języka polskiego jako obcego (w) "Język Polski", R. XCVIII, z. 2, str. 61-80.

${ }^{23}$ Przykładowo, zdający dany egzamin mogą mieć więcej czasu na lekturę tekstu, co stanowi czynnik ułatwiający rozwiązywanie zadania, ale utrudniać zrozumienie może np. abstrakcyjna tematyka czytanego materiału (zob. ESOKJ, 2003: 138-144). 
Certyfikatowe testy z języka polskiego i angielskiego na poziomie C2 w ujęciu...

Cambridge English Proficiency 2. Authentic examination papers with answers (2015), Cambridge: Cambridge University Press.

Cambridge English Proficiency. Handbook for teachers for exams from 2016 (2016), Cambride: Cambridge Assessment Group. Online: https:// www.c ambridgeenglish.org/ Images/168194-cambridge-english-proficiencyteachers-handbook.pdf [DW 10.12.2018]

Common European Framework of Reference for Languages: Learning, Teaching, Assessment. Companion Volume with New Descriptors (2018), Strasbourg: Council of Europe. Online: https:// rm.coe.int/cefr-companion-vol ume-with-new-descriptors-2018/1680787989 [DW 10.12.2018]

Docherty C., Howden D. (2013), Consulting stakeholders as part of the Cambridge English: Proficiency exam revisions (w) „Research notes”, nr 51, str. 18-21. Online: https:// www.cambridgeenglish.org/Images/130828research-notes-51-document.pdf [DW 03.12.2018]

Europejski system opisu kształcenia językowego: uczenie się, nauczanie, ocenianie (2003), Warszawa: Wydawnictwa CODN.

Komorowska H. (2002), Metodyka nauczania języków obcych. Warszawa: Fraszka Edukacyjna.

Lim G.S. (2013), Components of an elaborated approach to test validation (w) „Research notes", nr 51, str. 11-14. Online: https:// www.cambridgeenglish.org/l mages/130828-research-notes-51-document.pdf [DW 04.12.2018]

Państwowe Egzaminy Certyfikatowez J ęzyka Polskiego jako Obcego. Przykładowy test dla poziomu zaawansowanego: PL-C2 (2008), Warszawa: Państwowa Komisja Poświadczania Znajomości Języka Polskiego jako Obcego.

Państwowe Egzaminy Certyfikatowe z Języka Polskiego jako Obcego. Standardy wymagań egzaminacyjnych (2003), Warszawa: Państwowa Komisja Poświadczania Znajomości Języka Polskiego jako Obcego - M inisterstwo Edukacji Narodowej i Sportu.

Prizel-Kania A. (2018), Wpływ badań tekstów mówionych na dobór materiatów do egzaminów certyfikatowych z języka polskiego jako obcego - bilans dziesięciolecia (w) „J ęzyk Polski", R. XCVIII, z. 2, str. 81-95.

Seretny A., Lipińska E. (2005), ABC metodyki nauczania języka polskiego jako obcego. Kraków: Universitas.

Zeronis R., Elliot M . (2013), Development and construct of revised Cambridge English: Proficiency (w) „Research notes”, nr 51, str. 22-30. Online: https://ww w.cambridgeenglish.org/Images/130828-research-notes-51-document. pdf [DW 03.12.2018] 


\section{NETOGRAFIA}

http://certyfikatpolski.pl/dla-zdajacych/przykladowe-testy-zbiory-zadan/ [DW 04.12.2018]

http://praw 0.sejm.gov.pl/isap.nsf/DocDetails.xsp?id=WDU20030730661

[DW 26.11.2018]

http://prawo.sejm.gov.pl/isap.nsf/DocDetails.xsp?id=W DU20031911871

[DW 26.11.2018]

http://prawo.sejm.gov.pl/isap.nsf/DocDetails.xsp?id=W DU20150001132

[DW 26.11.2018]

http://prawo.sejm.gov.pl/isap.nsf/DocDetails.xsp?id=W DU20160000405

[DW 26.11.2018]

https://rm.coe.int/cefr-companion-volume-with-new-descriptors-2018/1680787989

[DW 28.11.2018]

https:// www.cambridgeenglish.org/exams-and-tests/cambridge-english-scale/ [DW 06.12. 2018]

https://www.cambridgeenglish.org/exams-and-tests/ proficiency/ preparation/ [DW 05.12. 2018] 